\title{
CAMA
}

Centre for Applied Macroeconomic Analysis

\section{Disentangling Commodity Demand, Commodity Supply, and International Liquidity Shocks on an Emerging Market}

\section{CAMA Working Paper 18/2020 February 2020}

Renee Fry-McKibbin

Centre for Applied Macroeconomic Analysis, ANU

Crawford School of Public Policy, ANU

Rodrigo da Silva Souza

Federal University of Viçosa

Centre for Applied Macroeconomic Analysis, ANU

\section{Abstract}

This paper examines the effects of commodity demand and supply shocks as well as international liquidity shocks on the small open economy of Brazil using an SVAR model. The paper highlights the importance of modeling both types of shocks in the commodity sector. Including only commodity prices overstates the effect of commodity price shocks on the output of Brazil. Commodity demand shocks are much larger than commodity supply shocks in the long run. Including commodity demand and international liquidity also reduces the impact of commodity price shocks on the interest rate made available to Brazil in international capital markets. The interest rate channel is considered a source of business cycles for emerging market economies in the literature. 


\section{Keywords}

Commodity demand shocks, commodity supply shocks, emerging market interest rates, liquidity, Brazil, SVAR

\section{JEL Classification}

C51, E32, F43, F62

\section{Address for correspondence:}

(E) cama.admin@anu.edu.au

\section{ISSN 2206-0332}

The Centre for Applied Macroeconomic Analysis in the Crawford School of Public Policy has been established to build strong links between professional macroeconomists. It provides a forum for quality macroeconomic research and discussion of policy issues between academia, government and the private sector.

The Crawford School of Public Policy is the Australian National University's public policy school, serving and influencing Australia, Asia and the Pacific through advanced policy research, graduate and executive education, and policy impact. 


\title{
Disentangling Commodity Demand, Commodity Supply, and International Liquidity Shocks on an Emerging Market*
}

\author{
Rodrigo da Silva Souza ${ }^{1}$ and Renée Fry-McKibbin ${ }^{2}$ \\ ${ }^{1}$ Federal University of Viçosa and CAMA \\ ${ }^{2}$ CAMA, Crawford School of Public Policy, Australian National University
}

February 24, 2020

\begin{abstract}
This paper examines the effects of commodity demand and supply shocks as well as international liquidity shocks on the small open economy of Brazil using an SVAR model. The paper highlights the importance of modeling both types of shocks in the commodity sector. Including only commodity prices overstates the effect of commodity price shocks on the output of Brazil. Commodity demand shocks are much larger than commodity supply shocks in the long run. Including commodity demand and international liquidity also reduces the impact of commodity price shocks on the interest rate made available to Brazil in international capital markets. The interest rate channel is considered a source of business cycles for emerging market economies in the literature.
\end{abstract}

KEYWORDs: Commodity demand shocks; commodity supply shocks; emerging market interest rates; liquidity, Brazil, SVAR.

JEL Classifications: C51; E32; F43; F62.

${ }^{*}$ We would like to thank Peter Nagle, Joaquin Vespignani and seminar participants at the World Bank for their comments on this paper. The authors gratefully acknowledge ARC Discovery Project funding DP200101963 and Coordenação de Aperfeiçoamento de Pessoal de Nível Superior - Brasil (CAPES). Author email addresses are renee.mckibbin@anu.edu.au and souzarodrigodasilva@gmail.com. The corresponding author is Renée Fry-McKibbin. 


\section{Introduction}

A feature of business cycles in emerging market economies is the counter-cyclical nature of the cost of borrowing faced in international financial markets (Neumeyer and Perri, 2005; Uribe and Yue, 2006). While developed economy interest rates are mildly pro-cyclical, in emerging markets periods of low-interest rates are associated with economic expansion and vice-versa because of the relatively large country-specific risk spread included in these rates (Fernández and Gulan, 2015). Also, the interest rate reacts to emerging market fundamentals, and fundamentals react to the interest rate, thereby exacerbating business-cycle fluctuations caused by real shocks. In an important extension, Shousha (2016) finds that real interest rates are counter-cyclical for emerging market economies, but that including commodity prices negates the role of the real interest rate as a source of business cycle fluctuations. The interest rate captures the effects of commodity price shocks if modelers omit commodity prices. Research shows that fluctuations in commodity prices are an important driver of emerging market business cycles (Fernández et al., 2018; Drechsel and Tenreyro, 2018; Zeev et al., 2017). ${ }^{1}$ Figure 1 plots the log of commodity prices against the interest rate available to Brazil in international markets. The figure suggests an inverse relationship between the two series. This relationship is confirmed in the correlation statistics contained in Table 1. The correlation between commodity prices and the interest rate is -0.80 .

A complementary strand of literature focuses on the role of liquidity in determining commodity prices. Globally, liquidity surged between 2005 and 2015 because of growth in Brazil, Russia, India, and China (the BRICs) and the policy responses to the great financial crisis, such as quantitative easing. Ratti and Vespignani (2013) and Ratti and Vespignani (2015) find that shocks to BRIC liquidity have large positive effects on commodity prices and that these effects are larger than those coming from G3 liquidity. Choi et al. (2017) find that global liquidity from advanced countries affects financial markets and currencies of emerging market economies, and also boosts their economic growth. Kang et al. (2016) find that the effects of global liquidity on commodity prices are more salient since the great financial crisis. Figure 1 also contains a plot of the liquidity of the BRICS and the US. For most of the sample, it does appear that the rise in liquidity tracks the rise in commodity prices, at least until the end of the commodities boom in 2014. The correlation between international liquidity and commodity prices is 0.58 .

We extend these works by empirically distinguishing between commodity demand and supply shocks in global commodity markets (Dungey et al., 2014, 2019), while also allowing a role for international liquidity (Ratti and Vespignani, 2015). We then examine the relative effects of the commodity sector and liquidity shocks on the macroeconomy of the emerging market economy of Brazil using a structural vector autoregression (SVAR) framework. Brazil is a

\footnotetext{
${ }^{1}$ Shousha (2016) finds that an increase in commodity prices reduces foreign country indebtedness due to an increase in exports which consequently lowers the interest rate in a DSGE framework. Since emerging market economies face financial frictions, the interest rate falls further due to lower country risk, which, in turn, directly relates to capital flows. Similarly, Drechsel and Tenreyro (2018), suggest that the negative relationship between the interest rate spread and commodity prices may come from creditors decreasing the required interest rate premium during the commodity price boom phase, as the collateral value of the economy depends directly on commodity prices through export earnings. For examples of the negative relationship between world commodity prices and country risk, see Bastourre et al. (2012); Aslam et al. (2016); Hilscher and Nosbusch (2010); Bouri et al. (2016) and Barone and Descalzi (2012). For an example of the link between large capital inflows and an increase in consumption, investment, and private credit, see Benigno et al. (2015). See Ornelas (2017) for an investigation of the influence of gross debt on the country spread.
} 


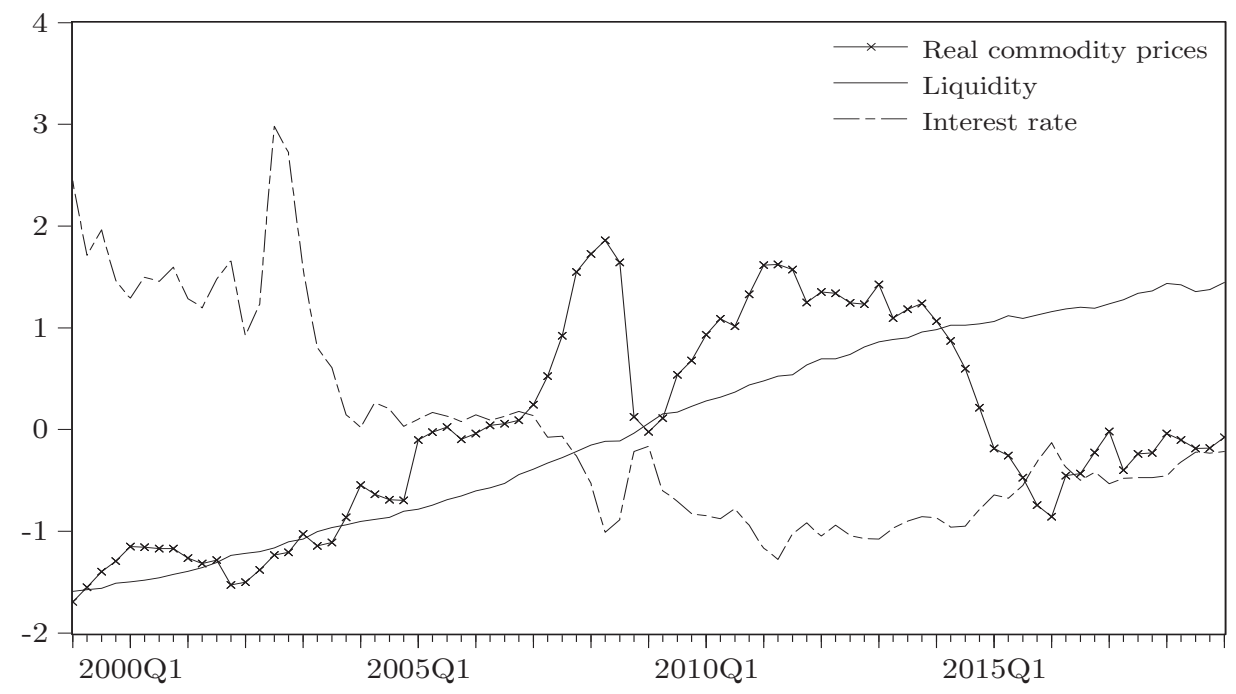

Figure 1: Real commodity prices, liquidity and the interest rate, 1999Q1 to 2019Q1.

Notes: The data are in log form and the scale is normalized. The real commodity price variable is a trade-weighted index containing prices of Brazil's three primary commodity exports (soybeans, iron ore and oil). Liquidity is the sum of the M2 of Brazil, Russia, India, China, and the U.S. The interest rate is the sum of the JP Morgan EMBI+ sovereign spread and the U.S. real interest rate. For details on data construction and sources, see Section 2.1 and Appendix A.

pertinent case to empirically assess these relationships as it is the largest economy in Latin America and a significant supplier of commodities to global markets. Brazil is the world's largest exporter of soybeans and the second largest of iron ore and is a substantial exporter of oil. The demand for Brazil's exports comes mostly from China. ${ }^{2}$ Current evidence points to substantial spillover effects of the unprecedented demand for commodities for Chinese industrialization to commodity-exporting countries (Cesa-Bianchi et al., 2012; Dungey et al., 2019), and that the impacts of Chinese economic shocks on a typical Latin American economy have tripled since mid-1990 (Cesa-Bianchi et al., 2012). The SVAR model contains an external sector consisting of Chinese resource demand, international liquidity, world commodity prices, and foreign output, as well as a domestic sector for the macroeconomy of Brazil. The commodity demand and supply shocks are distinguished by including both Chinese resource demand and commodity prices in the model. The correlations contained in Table 1 show that the correlation between Chinese resource demand and commodity prices, and Chinese resource demand and international liquidity are also relatively high with coefficients of 0.83 and 0.41 , respectively.

Our findings highlight the mechanisms through which the external commodity sector acts as an important driver of business cycles in the Brazilian economy. Chinese resource demand shocks epitomize commodity demand shocks, and commodity prices epitomize commodity supply shocks. The effects of shocks to Chinese resource demand are large and result in real exports rising by $7 \%$ in the fourth quarter and domestic output by $1 \%$ in 3.5 years. In the

\footnotetext{
${ }^{2}$ Exports of soybeans, iron ore, and oil accounted for $22 \%$ of Brazil's total exports in 2018. China purchased $82 \%$ of Brazil's soybean exports, $54 \%$ of iron ore exports, and $57 \%$ of oil exports in the same year. The data are available at http://comexstat.mdic.gov.br/.
} 
Table 1: Correlation of key variables with Chinese resource demand, liquidity, real commodity prices and Brazilian output, 1999Q1 to 2019Q1.

\begin{tabular}{lcccc}
\hline \hline \multirow{5}{*}{ Variable } & \multicolumn{4}{c}{ Correlation with } \\
\cline { 2 - 5 } & $\begin{array}{c}\text { Chinese resource } \\
\text { demand } \\
(1)\end{array}$ & $\begin{array}{c}\text { Liquidity } \\
\text { Real commodity } \\
\text { prices } \\
(3)\end{array}$ & $\begin{array}{c}\text { Domestic } \\
\text { output } \\
(4)\end{array}$ \\
\hline Liquidity & 0.41 & 1.00 & 0.58 & 0.82 \\
Real commodity prices & 0.83 & 0.58 & 1.00 & 0.87 \\
Resource exports & 0.78 & 0.56 & 0.90 & 0.83 \\
Investment & 0.58 & 0.88 & 0.79 & 0.96 \\
Consumption & 0.49 & 0.92 & 0.69 & 0.91 \\
Domestic output & 0.76 & 0.82 & 0.87 & 1.00 \\
Interest rate & -0.78 & -0.52 & -0.80 & -0.75 \\
Real exchange rate & -0.53 & -0.62 & -0.74 & -0.70 \\
& & & & \\
\hline
\end{tabular}

Notes: All variables are linearly detrended and expressed in log form. Chinese resource demand is proxied by Chinese steel production; liquidity is the sum of the M2 of Brazil, Russia, India, China, and the U.S.; the real commodity price variable is a trade-weighted index containing prices of Brazil's three primary commodity exports (soybeans, iron ore and oil); Brazilian resource exports are the sum of soybeans, iron ore and oil; the real exchange rate is a trade-weighted index defined in terms of a basket of foreign goods such that a decrease is a real appreciation of the Brazilian real; and the interest rate is the sum of the JP Morgan EMBI+ sovereign spread and the U.S. real interest rate. For complete details on data construction and sources see Section 2.1 and Appendix A.

short run, output, Chinese resource demand, and commodity price shocks explain the variance of output. Our decomposition of the variance of domestic output attributes a remarkable $46 \%$ to Chinese resource demand shocks and $8 \%$ to shocks to world commodity prices over the longer time horizon. Recent works find that commodity price shocks explain approximately one-third of business cycle fluctuations in emerging economies (Shousha, 2016; Drechsel and Tenreyro, 2018; Fernández et al., 2018). In contrast, our contribution shows that the bulk of the influence of the commodity sector on economic fluctuations in Brazil comes from Chinese demand rather than commodity price shocks. International liquidity and world output each contribute over $20 \%$. Commodity prices contribute the least of the international variables to the variance of output. Shocks to world commodity prices do produce an expansionary effect on the Brazilian economy. However, the effects are less persistent than the shocks from Chinese resource demand. In the long term, the effects of domestic shocks in explaining the variance in output are negligible.

Our results confirm the findings of Shousha (2016), who shows that the inclusion of commodity price shocks dampens the contribution of interest rate shocks on domestic output (Uribe and Yue, 2006). However, this is subject to the caveat that including Chinese resource demand and liquidity in the model reduces the contribution of world commodity prices in explaining the variance of the interest rate compared to that found in the previous literature. For example, using data from 1995Q1 to 2014Q3, Zeev et al. (2017) show that world commodity price fluctuations explain $26 \%$ of the variance in the interest rate spread. Our 
results show that the shocks to Chinese resource demand and liquidity have almost equal importance after 36 quarters of $27 \%$ and $22 \%$, respectively, while shocks to world commodity prices contribute about $6 \%$. In turn, the interest rate plays a smaller role in explaining the variance in domestic output than that found in previous literature. This is an important result for Brazil given their historically high interest rates.

The shock to international liquidity leads to an increase in real commodity prices consistent with Ratti and Vespignani (2015). We further contribute to this literature on the effects of liquidity shocks by examining their effects on the macroeconomic outcomes of Brazil. Liquidity shocks lead to a domestic currency appreciation and a fall in the interest rate. The fall in the interest rate reflects the expectations of foreign investors of improvement of economic fundamentals in Brazil and hence the rate at which they are willing to lend, stimulating domestic output. It is not increased revenue from commodity prices and resource exports that leads to the expansionary effect on the economy in response to the liquidity shock. In turn, we find that liquidity responds to the demand shock coming from China, but not to the supply shock reflected in the commodity price series.

The rest of this paper proceeds as follows. Section 2 describes the data and the empirical framework for the commodity-macroeconomic model for Brazil. Section 3 presents the impulse response functions for the commodity sector and liquidity shocks, Section 4 presents the forecast error variance decomposition of output and the interest rate, and 5 presents the historical decomposition for the same variables. Section 6 examines the robustness of the results for output for alternative assumptions on the model and data. Section 7 concludes.

\section{Empirical framework}

This section outlines an SVAR model for Brazil to gauge the effects of shocks to Chinese resource demand, international liquidity, and commodity prices on the macroeconomy. Section 2.1 presents the data and 2.2 outlines the model and the identification assumptions.

\section{$2.1 \quad$ Data}

The dataset $\left(X_{t}\right)$ consists of four international and six domestic variables. The international variables are Chinese resource demand $\left(c s p_{t}\right)$, liquidity using M2 of the BRICs and the U.S. $\left(l i q_{t}\right)$, real commodity prices $\left(p c_{t}\right)$, and real foreign output $\left(y w_{t}\right)$. The domestic variables are real Brazilian exports $\left(\right.$ res $\left.x_{t}\right)$, a measure of the non-tradable primary commodity sector $\left(\mathrm{comm}_{t}\right)$, domestic output $\left(y d_{t}\right)$, inflation $\left(p d_{t}\right)$, the interest rate $\left(r d_{t}\right)$, and a real exchange rate $\left(q_{t}\right)$. The dataset is summarized by

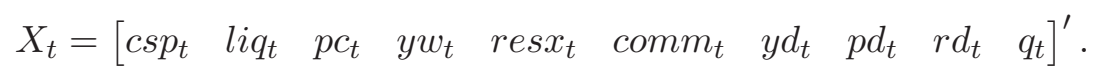

The sample ranges from 1999Q1 to 2019Q1 with the start date coinciding with the adoption of the macroeconomic tripod (floating exchange rate, inflation target and primary surplus target). Although it is common for SVAR papers on the Brazilian economy to begin their sample period in 1996 or before (Zeev et al., 2017), a floating currency is a shock-absorber of terms of trade shocks (Aslam et al., 2016) and represents an important break in the exchange rate data for the research question. 
Chinese steel production $\left(c s p_{t}\right)$ serves as a proxy of Chinese resource demand as there is no direct measure of Chinese resource demand (Dungey et al., 2014, 2019). Section 6 explores alternative proxies of Chinese resource demand. The sum of the M2 of Brazil, Russia, India, China, and the U.S. is the measure of international liquidity $\left(l i q_{t}\right)$. Ratti and Vespignani (2015) show that BRIC liquidity is an essential factor in commodity prices, and we add to that U.S. liquidity because of its importance to the monetary system, to Brazil, and the Latin American region. The monetary aggregates are deflated by the corresponding domestic consumer price index and transformed into U.S. dollars by the nominal exchange rate at the end of each quarter. L2 is used as a proxy for M2 for India, as the latter is not available for the entire sample. Foreign output $\left(y w_{t}\right)$ is the real GDP of Brazil's twenty largest trading partners weighted in terms of the average value of Brazilian exports to each country.

We construct a commodity price index $\left(p c_{t}\right)$ for the principal commodities that Brazil exports. Namely iron ore, soybeans, and oil. The calculation of the index follows the method of Deaton and Miller (1996) and Cashin et al. (2004) and is a geometrically weighted real index. The value of the exports of each commodity is divided by the value of Brazil's total commodity exports to calculate the weights for the commodities used in the price index for each month. The index is expressed in U.S. dollars and converted to a real index by diving the nominal commodity price index by the U.S. consumer price index. ${ }^{3}$ The average weights of the commodities in the total index are $40.00 \%$ for iron ore, $33.10 \%$ for soybeans and $26.90 \%$ for oil. The quarterly values are the average over the quarter. The real resource export variable $\left(r e s x_{t}\right)$ for Brazil consists of the same products included in the commodity price index.

The measure of the primary non-tradable commodity sector $\left(\mathrm{comm}_{t}\right)$ sums the value-added of the crop and livestock sector and the mining sector. The crop and livestock sector has a strong relationship with exported agricultural goods (soybeans), and the mining sector has a strong relationship with exported mineral goods (iron ore and oil). Non-tradable sectors and hence the macroeconomy can be adversely affected by commodity price booms described in the literature on Dutch disease where domestic currency appreciation crowds out export markets not related to commodities and by resource reallocation from the non-commodity sectors to the commodity sector (Corden and Neary, 1982; Corden, 1984).

Domestic output $\left(y d_{t}\right)$ is Brazilian real GDP. The inflation rate $\left(p d_{t}\right)$ is the Broad National Consumer Price Index (IPCA), which is the primary indicator of the inflation target of the Central Bank of Brazil. The construction of the interest rate $\left(r d_{t}\right)$ follows Uribe and Yue (2006) and Shousha (2016) and is the sum of JP Morgan's EMBI+ sovereign spread for Brazil and the U.S. real interest rate. The three-month U.S. Treasury bill minus a measure of U.S. expected inflation measures the latter. The real exchange rate $\left(q_{t}\right)$ is the Central Banks tradeweighted index expressed in real terms using the IPCA. The inclusion of the real exchange rate links with the literature on the influence of external shocks on emerging market economies (Shousha, 2016; Fernández et al., 2018; Zeev et al., 2017; Drechsel and Tenreyro, 2018) and also to the literature on the impact of commodity booms on commodity-exporting economies (Dungey et al., 2014; Corden, 1984; Corden and Neary, 1982; Frankel, 2012; van Wijnbergen, 1984). Appendix A contains full details of the data and data sources.

All variables except for the inflation rate are in logs and linearly detrended, which means that the interpretation of the impulse response functions is of the dynamics of a variable around

\footnotetext{
${ }^{3}$ The U.S. CPI is for all urban consumers. Dungey et al. (2014) also use the U.S. CPI to deflate the nominal price index, while Shousha (2016) and Zeev et al. (2017) use the U.S. import price of manufactured goods from industrialized countries to calculate the commodity terms of trade.
} 
the data-specific steady-state or trend (Dungey and Pagan, 2000). The inflation rate is in percent. Section 6 explores the assumption of the trends in the data.

\subsection{The SVAR model and identification}

The SVAR model for the set of variables $X_{t}$ in Equation (2) is

$$
B_{0} X_{t}=B_{1} X_{t-1}+B_{2} X_{t-1}+\epsilon_{t}
$$

$B_{0}$ represents the contemporaneous relationships between the variables and is non-singular and normalized to have unit values on the diagonal. $B_{1}$ and $B_{2}$ are the structural parameters on the lagged endogenous variables for a lag length of $p=2$. $\epsilon_{t}$ is a $10 \times 1$ vector of normally distributed structural shocks with $E\left(\epsilon_{t} \epsilon_{t}^{\prime}\right)=D$ and $E\left(\epsilon_{t} \epsilon_{t+s}^{\prime}\right)=0$, for all $s \neq 0$. The diagonal matrix $D$ contains the variances used to calculate the structural shocks. The constant term is suppressed for convenience.

The identification of the structural shocks in the SVAR takes place through lower triangular restrictions on the contemporaneous impact matrix $B_{0}$ and through restrictions on the parameter matrices of the lags $B_{1}$ and $B_{2}$. Building on the identification assumptions in Dungey et al. (2014) and Dungey et al. (2019), the general ordering follows the order of the variables in Equation (1).

Chinese resource demand comes first given that for most of the sample, Chinese demand was domestically generated and less dependent on the international economy than the other foreign variables. Liquidity comes before world commodity prices, and foreign output, assuming that real variables do not respond contemporaneously to financial variables. Commodity prices react to Chinese resource demand and liquidity in the BRICs and the U.S. contemporaneously. ${ }^{4}$ Ratti and Vespignani (2015) also order BRIC and G3 liquidity before commodity prices. The last variable in the international sector is foreign output. The international variables affect each other through the lags.

As Brazil is a small open economy with little capacity to affect the global economy, the international variables in $X_{t}$ affect all domestic variables contemporaneously, but the domestic variables do not affect the international variables contemporaneously or through the lags. The resource exports and the non-tradable commodity sector respond to the international sector contemporaneously. The identification of the remaining macroeconomic variables generally follows the lower triangular ordering with exceptions for the inflation rate and the interest rate, where there are zero restrictions on Chinese steel production, world output, and resource exports contemporaneously (Berkelmans, 2005; Dungey et al., 2014). The only foreign variables able to affect inflation and the interest rate are liquidity and commodity prices. The interest rate influences the domestic variables after one lag, and shocks to the domestic macroeconomic variables affect the financial market variables of the interest rate and the exchange rate contemporaneously in common with previous models specified for emerging market economies (Uribe and Yue, 2006; Shousha, 2016). ${ }^{5}$

\footnotetext{
${ }^{4}$ Section 6 contains a sensitivity to the ordering of commodity prices.

${ }^{5}$ According to Uribe and Yue (2006) financial markets react quickly to news about the business cycles in emerging economies. Moreover, decisions about real activity such as employment and spending on investment goods take time to implement.
} 
The contemporaneous identification restrictions are summarized by

$$
B_{0} X_{t}=\left[\begin{array}{cccccccccc}
1 & 0 & 0 & 0 & 0 & 0 & 0 & 0 & 0 & 0 \\
b_{2,1} & 1 & 0 & 0 & 0 & 0 & 0 & 0 & 0 & 0 \\
b_{3,1} & b_{3,2} & 1 & 0 & 0 & 0 & 0 & 0 & 0 & 0 \\
b_{4,1} & b_{4,2} & b_{4,3} & 1 & 0 & 0 & 0 & 0 & 0 & 0 \\
b_{5,1} & b_{5,2} & b_{5,3} & b_{5,4} & 1 & 0 & 0 & 0 & 0 & 0 \\
b_{6,1} & b_{6,2} & b_{6,3} & b_{6,4} & b_{6,5} & 1 & 0 & 0 & 0 & 0 \\
b_{7,1} & b_{7,2} & b_{7,3} & b_{7,4} & b_{7,5} & b_{7,6} & 1 & 0 & 0 & 0 \\
0 & b_{8,2} & b_{8,3} & 0 & 0 & b_{8,6} & b_{8,7} & 1 & 0 & 0 \\
0 & b_{9,2} & b_{9,3} & 0 & 0 & b_{9,6} & b_{9,7} & b_{9,8} & 1 & 0 \\
b_{10,1} & b_{10,2} & b_{10,3} & b_{10,4} & b_{10,5} & b_{10,6} & b_{10,7} & b_{10,8} & b_{10,9} & 1
\end{array}\right]\left[\begin{array}{c}
c s p_{t} \\
l i q_{t} \\
p c_{t} \\
y w_{t} \\
r e s x_{t} \\
c o m m_{t} \\
y d_{t} \\
p d_{t} \\
r d_{t} \\
q_{t}
\end{array}\right]
$$

and the identification restrictions through the lags for $j=1,2$ are by ${ }^{6}$

$$
B_{j} X_{t-j}=\left[\begin{array}{cccccccccc}
b_{1,1}^{j} & b_{1,2}^{j} & b_{1,3}^{j} & b_{1,4}^{j} & 0 & 0 & 0 & 0 & 0 & 0 \\
b_{2,1}^{j} & b_{2,2}^{j} & b_{2,3}^{j} & b_{2,4}^{j} & 0 & 0 & 0 & 0 & 0 & 0 \\
b_{3,1}^{j} & b_{3,2}^{j} & b_{3,3}^{j} & b_{3,4}^{j} & 0 & 0 & 0 & 0 & 0 & 0 \\
b_{4,1}^{j} & b_{4,2}^{j} & b_{4,3}^{j} & b_{4,4}^{j} & 0 & 0 & 0 & 0 & 0 & 0 \\
b_{5,1}^{j} & b_{5,2}^{j} & b_{5,3}^{j} & b_{5,4}^{j} & b_{5,5}^{j} & 0 & 0 & 0 & 0 & b_{5,10}^{j} \\
b_{6,1}^{j} & b_{6,2}^{j} & b_{6,3}^{j} & b_{6,4}^{j} & b_{6,5}^{j} & b_{6,6}^{j} & b_{6,7}^{j} & b_{6,8}^{j} & b_{6,9}^{j} & b_{6,10}^{j} \\
b_{7,1}^{j} & b_{7,2}^{j} & b_{7,3}^{j} & b_{7,4}^{j} & b_{7,5}^{j} & b_{7,6}^{j} & b_{7,7}^{j} & b_{7,8}^{j} & b_{7,9}^{j} & b_{7,10}^{j} \\
b_{8,1}^{j} & b_{8,2}^{j} & b_{8,3}^{j} & b_{8,4}^{j} & b_{8,5}^{j} & b_{8,6}^{j} & b_{8,7}^{j} & b_{8,8}^{j} & b_{8,9}^{j} & b_{8,10}^{j} \\
b_{9,1}^{j} & b_{9,2}^{j} & b_{9,3}^{j} & b_{9,4}^{j} & b_{9,5}^{j} & b_{9,6}^{j} & b_{9,7}^{j} & b_{9,8}^{j} & b_{9,9}^{j} & b_{9,10}^{j} \\
b_{10,1}^{j} & b_{10,2}^{j} & b_{10,3}^{j} & b_{10,4}^{j} & b_{10,5}^{j} & b_{10,6}^{j} & b_{10,7}^{j} & b_{10,8}^{j} & b_{10,9}^{j} & b_{10,10}^{j}
\end{array}\right]\left[\begin{array}{c}
c s p_{t-j} \\
l i q_{t-j} \\
p c_{t-j} \\
y w_{t-j} \\
r e s x_{t-j} \\
c o m m_{t-j} \\
y d_{t-j} \\
p d_{t-j} \\
r d_{t-j} \\
q_{t-j}
\end{array}\right] .
$$

\section{Commodity sector and international liquidity shocks}

This section presents the impulse response functions of the effects of shocks to Chinese resource demand $\left(c s p_{t}\right)$, international liquidity $\left(l i q_{t}\right)$, and real commodity prices $\left(p c_{t}\right)$ on the macroeconomy of Brazil. The three columns of Figure 2 contain the impulse response functions for one standard deviation shocks to Chinese resource demand, international liquidity, and commodity prices, respectively. The dashed lines are the one standard deviation error bands. The shocks to Chinese steel production and commodity prices neatly resemble commodity demand and supply shocks. The demand shock has more persistence for output than the supply shock. The liquidity shock leads to a rise in output through stimulus coming from lower interest rates rather than through a rise in export volumes.

Shock to Chinese resource demand The shock to Chinese steel production has the characteristics of a commodity demand shock. The one standard deviation shock to Chinese steel production leads to rising real commodity prices and real foreign output, as shown in the first column of Figure 2. Commodity prices peak at $2.75 \%$ above the baseline three quarters after the shock. Chinese steel production and commodity prices converge to their initial values approximately 27 and 31 quarters after the shock, respectively. The response of Brazilian real

\footnotetext{
${ }^{6}$ The VAR lag order selection tests indicate either one or two lags. We choose two lags as this ensures no serial correlation, and the VAR satisfies the stability condition. The model also satisfies the overidentification test of the restrictions in the model.
} 
resource exports is large, peaking at $7.00 \%$ above the baseline four quarters after the shock. The rise in resource exports occurs despite an appreciation of the real exchange rate indicating high profitability of resource exports for Brazil consistent with Veríssimo and Xavier (2013). Higher Chinese resource demand and the resulting commodity price boom translate into an expansion of output in Brazil, which has longevity. Domestic output first peaks at $0.87 \%$ above baseline in the third quarter following the shock, but then peaks again at $1.02 \% 14$ quarters after the shock and remains above the baseline for nine years. An expansion also occurs in the primary non-tradable commodity sector with a rise of $1.22 \%$. That all sectors expand in response to the commodity demand shock suggests that, on average, there is no evidence of Dutch disease for Brazil (Corden, 1984; Corden and Neary, 1982; Dungey et al., 2019).

The commodity demand shock puts downward pressure on the interest rate available to Brazil in foreign capital markets. The shock leads to monetary expansion and an increase in international liquidity, while investors expect higher growth in Brazil as the commodity prices rise and the terms of trade move favorably (Shousha, 2016). These channels contribute to the overall expansionary effect of the shock and support the existence of a counter-cyclical relationship between interest rates and the business cycle in emerging markets (Neumeyer and Perri, 2005; Uribe and Yue, 2006). The combined effect of a resource boom with a monetary expansion leads to a further expansion in commodity-exporting economies. ${ }^{7}$

The increase in commodity exports and the decline in the interest rate lead to an appreciation of the real exchange rate. The responses of all of the domestic variables have longevity. For example, the primary non-tradable commodity sector deviates from baseline for 24 quarters, the interest rate for 32 quarters, and the exchange rate for 33 quarters. The average duration of the responses is similar to that of the duration of the shock to Chinese resource demand. The exception is inflation, which is neutralized by the appreciation of the real exchange rate.

Shock to liquidity The shock to international liquidity leads to an increase in real commodity prices, consistent with Ratti and Vespignani (2015), but does not affect Chinese steel production or foreign output. The negligible effects of liquidity on Chinese steel production reflects that Chinese industrialization is a domestic phenomenon. Investors expect increased revenue from exports, stronger economic fundamentals, and higher growth because of the rise in commodity prices. The domestic currency appreciates, and the interest rate in Brazil falls, reflecting the expectation of stronger fundamentals. Domestic output rises but not because of stimulus to resource exports or to the non-tradable primary commodity sector. In fact, contrary to perception, the volume of resource exports does not respond significantly to the shock to liquidity and the rise in commodity prices. The rise in output comes from the stimulus to the domestic economy through the lower interest rates, as well as to the increased revenue for exports coming through higher export prices, but not through an increase in export volumes. The increase in liquidity has little effect on inflation.

Shock to commodity prices The shock to real commodity prices has the characteristics of a commodity supply shock. While the price of commodities initially rises $4.08 \%$ above the baseline, the quantity of steel produced in China initially falls, as shown in column three of Figure 2. Foreign output initially rises but falls at the end of the first year as the increase in the price of inputs into production, and hence prices of final goods lead to a fall in foreign demand (Jääskelä and Smith, 2013). While liquidity responds positively and significantly to

\footnotetext{
${ }^{7}$ This result differs from that documented for developed countries such as Australia, where the interest rate response to the demand shock is positive (Dungey et al., 2019).
} 
the demand shock coming from China, it does not respond to the commodity supply shock.

The effect on real Brazilian resource exports is substantial and mirrors the trajectory of world commodity prices. Brazilian resource exports peak at $9.02 \%$ above baseline in the third quarter and remain above baseline for six years. The rise in resource exports occurs despite a real appreciation of the domestic currency, which is also the case for the commodity demand shock. The non-tradable primary commodity sector in Brazil fluctuates around the baseline in response to a commodity supply shock but is mostly not significant. Resource demand shocks affect the non-tradable primary commodity sector, while the resource supply shocks do not.

Domestic output peaks at a low $0.43 \%$ above baseline in the third quarter following the commodity supply shock. The effect is significant for ten quarters. Brazil's interest rate falls and remains below baseline for seven years. The response of the interest rate is similar in sign to the response for the commodity demand shock but is significant for a shorter period. The reaction of domestic output and the interest rate confirm the findings reported by Zeev et al. (2017), Shousha (2016), Drechsel and Tenreyro (2018) and Fernández et al. (2018), who suggest that world commodity prices are a source of business cycles in Latin America because they reduce the country's interest rate, causing a further expansion in output that would not otherwise occur. The spillover effect from commodity prices to the interest rate helps to explain the expansionary impact of the shocks to commodity prices on the overall economy.

The domestic currency appreciates in response to the higher world commodity prices over a seven-year time-frame. The exchange rate follows the trajectory of higher resource exports and the lower interest rate closely. As the interest rate measures the cost of borrowing that emerging countries face in international financial markets, a decrease in that rate leads to capital inflows, which puts further pressure on the real exchange rate. Indeed, Shousha (2016) argues that the interest rates of emerging market economies rise when there are capital outflows, while in advanced economies, interest rate rises are mainly due to monetary policy tightening. As for the shock to liquidity, the appreciation of the real exchange rate neutralizes any effect on inflation.

\section{Forecast error variance decomposition}

This section contains the variance decomposition of Brazilian output and the interest rate. Table 2 provides the results with output in the top panel and the interest rate in the bottom panel. The right column of the table shows the variance decomposition if we omit the Chinese steel production variable from the model. The section shows that international influences dominate the macroeconomy of Brazil in the long-run. However, commodity demand and supply shocks need to be separately identified. Chinese steel production and liquidity reduce the impact of commodity prices in the model in the long term decomposition of the macroeconomy. The section also contains likelihood ratio tests confirming that the international variables in the model are individually and jointly significant for the macroeconomy.

Decomposition of output In the short-run, own shocks contribute most to the variance of domestic output, accounting for $73 \%$ and $19 \%$ at horizons one and four, respectively. The commodity sector of Chinese steel production and commodity prices are the next principal contributors. Chinese steel production contributes $11 \%$ and $39 \%$ to the variance of output at 

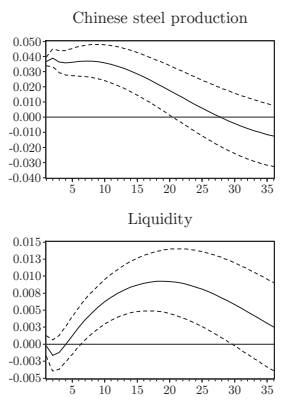

Real commodity prices

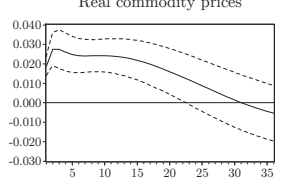

Foreign output

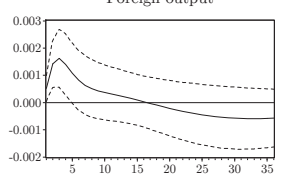

Resource exports

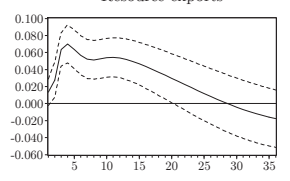

Primary commodity sector

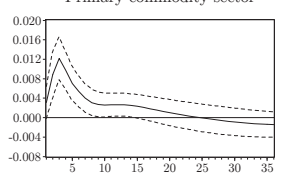

Domestic output

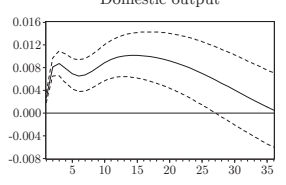

Inflation

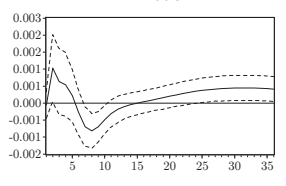

Interest rate

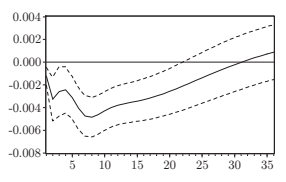

Real exchange rate

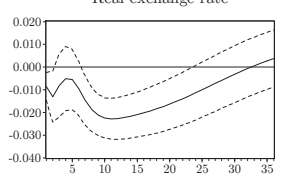

(a)

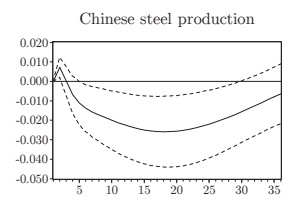

Liquidity

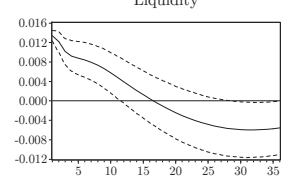

Real commodity prices

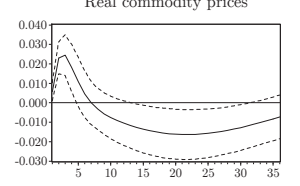

Foreign output

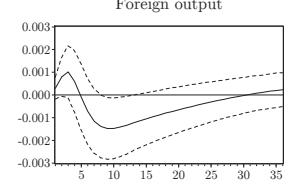

Resource exports

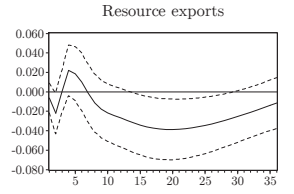

Primary commodity sector

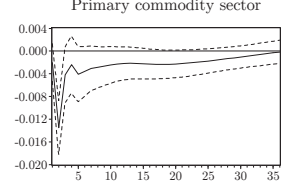

Domestic output

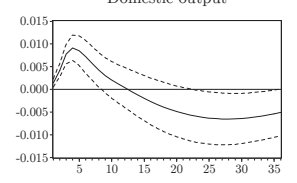

Inflation

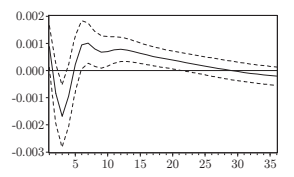

Interest rate

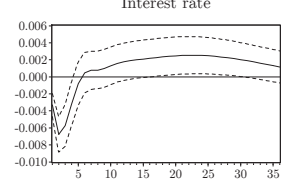

Real exchange rate

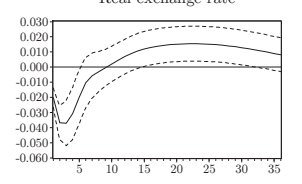

(b)

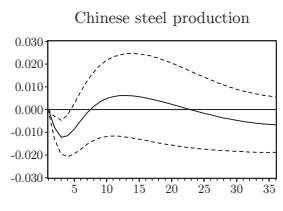

Liquidity

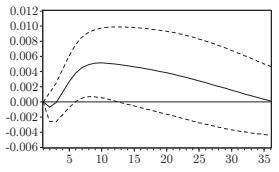

Real commodity prices

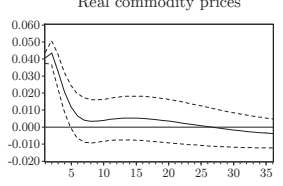

Foreign output

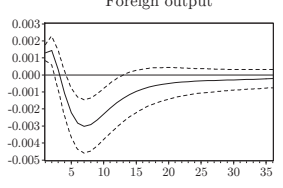

Resource exports

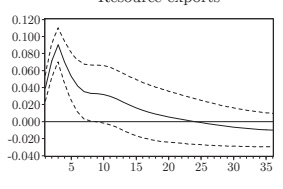

Primary commodity secto

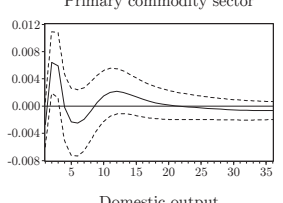

Domestic output

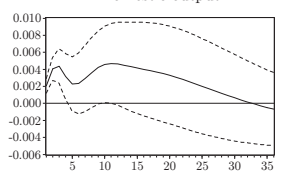

Inflation

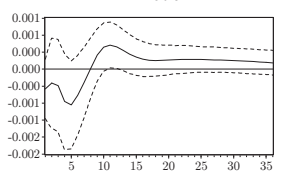

Interest rate

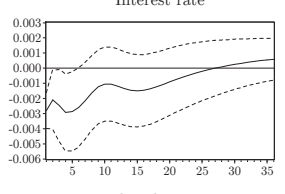

Real exchange rate

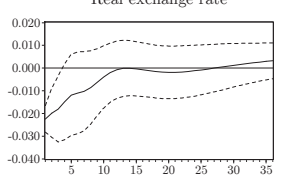

(c)

Figure 2: Impulse response functions to a shock to Chinese steel production (column a), liquidity (column b) and real commodity prices (column c), 1999Q1 to 2019Q1. 
horizons one and four, while commodity prices contribute $6 \%$ and $9 \%$ at the same horizons.

Longer-term, the decomposition shows the susceptibility of the Brazilian economy to external shocks. Over the horizon of 36 quarters, shocks in Chinese steel production (46\%), liquidity $(23 \%)$, world commodity prices $(8 \%)$, and world demand (20\%) combine to contribute $97 \%$ to the variance of domestic output. ${ }^{8}$ Our key finding is that although commodity prices have a non-trivial role for Brazilian output in the longer term, the commodity demand side has a stronger role in the business cycle of Brazil. Once we control for Chinese resource demand, commodity prices are not even the second most influential variable. International liquidity and world output each contribute three times more than commodity prices. ${ }^{9}$

The interest rate often considered essential in accounting for business cycles in emerging market economies (Neumeyer and Perri, 2005; Uribe and Yue, 2006), explains only $0.29 \%$ of Brazilian output. This result partially confirms Shousha (2016), who argues that if commodity prices are omitted from such models for commodity exporters, the interest rate shocks capture commodity price effects leading to an overestimation of the interest rate for the business cycle. We clarify this result by finding that the impact of commodity price shocks are, in turn, overestimated if commodity demand and supply shocks are not distinguished. Table 2 presents a variance decomposition of the model estimated without the Chinese steel production variable, which proxies the commodity demand element of the model. The results show that commodity prices now account for $70 \%$ of the variance of the output of Brazil compared to $8 \%$ for the model containing both commodity demand and supply shocks. Liquidity still accounts for around a fifth of the variance of output after 36 quarters.

Decomposition of the interest rate The bottom panel of Table 2 presents the variance decomposition of the interest rate, with and without Chinese resource demand. Previous work finds that commodity price fluctuations explain the variance in the interest rate spread in Brazil (Zeev et al., 2017). Our results show that the main determinants of the interest rate after four quarters are interest rate shocks and liquidity shocks contributing about $50 \%$ and $23 \%$, respectively. After a year, commodity prices and Chinese resource demand contribute equally (both at $6 \%$ ). After 36 quarters, the order of importance of the contributions change and Chinese resource demand and liquidity dominate the effect of commodity prices for explaining the interest rate. The commodity price contribution remains at around $6 \%$ of the total, while Chinese resource demand and liquidity increase to $27 \%$ and $22 \%$, respectively. The effect of the own shocks falls to $22 \%$ of the total. The second column of the bottom panel of Table 2 shows that omitting Chinese resource demand results in commodity prices dominating the decomposition of the interest rate at $48 \%$ of the variance after 36 quarters. Our results extend those of Ratti and Vespignani (2015) that liquidity explains commodity prices to show that liquidity also matters for macroeconomic variables of the output and the interest rate. ${ }^{10}$ We add the caveat that commodity demand and supply shocks also need to be distinguished.

Tests of international linkages for Brazil Table 3 presents the formal likelihood ratio

\footnotetext{
${ }^{8}$ Sensitivity to the treatment of the trends in the model is contained in Section 6 . The key results hold in the alternative model.

${ }^{9}$ The results for Brazil are unlike the findings in Dungey et al. (2019) for Australia that show that at the longer horizon, Chinese steel production and world commodity prices are responsible for $4.95 \%$ and $9.32 \%$ of Australian output, respectively. The contrasting results align with Shousha (2016), who finds that real commodity prices are responsible for $23 \%$ of the movement in the domestic output of emerging market economies compared with $7 \%$ of that in advanced economies.

${ }^{10}$ The decomposition of commodity prices shows that liquidity contributes $25 \%$ after 36 quarters.
} 
Table 2: Forecast error variance decomposition of output and the interest rate for Brazil, 1999Q1 to 2019Q1 (in per cent). Panels (b) and (d) compare the decomposition for a model not containing Chinese resource demand.

\begin{tabular}{|c|c|c|c|c|c|c|c|c|c|}
\hline \multicolumn{5}{|c|}{ Horizon (quarter) } & \multicolumn{5}{|c|}{ Horizon (quarter) } \\
\hline 1 & 4 & 12 & 24 & 36 & 1 & 4 & 12 & 24 & 36 \\
\hline
\end{tabular}

(a) output with $c s p_{t}$

(b) output without $c s p_{t}$

$\begin{array}{lrrrrrllllll}\text { csp }_{t} & 10.65 & 38.54 & 41.24 & 48.84 & 45.82 & & & & & & \\ \text { liq } & 2.87 & 29.69 & 19.84 & 15.54 & 23.30 & \text { liq } & 1.92 & 28.56 & 23.58 & 16.66 & 17.77 \\ \text { pct } & 6.05 & 9.09 & 9.24 & 8.70 & 7.56 & p c_{t} & 19.12 & 48.29 & 62.98 & 70.77 & 69.91 \\ y w_{t} & 0.41 & 1.36 & 22.06 & 23.21 & 20.21 & \text { yw } w_{t} & 1.32 & 1.64 & 6.42 & 7.85 & 7.74 \\ \text { resx }_{t} & 2.22 & 0.54 & 0.28 & 0.14 & 0.11 & \text { resx } & 0.99 & 0.69 & 0.56 & 0.37 & 0.36 \\ \text { comm }_{t} & 5.08 & 1.10 & 0.54 & 0.27 & 0.22 & \text { comm } & 6.44 & 1.31 & 0.43 & 0.29 & 0.28 \\ y d_{t} & 72.72 & 18.84 & 5.88 & 2.86 & 2.39 & y d_{t} & 70.21 & 18.51 & 4.94 & 3.31 & 3.22 \\ p d_{t} & 0.00 & 0.04 & 0.06 & 0.03 & 0.02 & p d_{t} & 0.00 & 0.01 & 0.04 & 0.03 & 0.03 \\ r d_{t} & 0.00 & 0.71 & 0.72 & 0.35 & 0.29 & r d_{t} & 0.00 & 0.86 & 0.71 & 0.48 & 0.46 \\ q_{t} & 0.00 & 0.09 & 0.14 & 0.07 & 0.06 & q_{t} & 0.00 & 0.13 & 0.34 & 0.23 & 0.22\end{array}$

(c) interest rate with $c s p_{t}$

(d) interest rate without $c s p_{t}$

\begin{tabular}{|c|c|c|c|c|c|c|c|c|c|c|c|}
\hline$c s p_{t}$ & 1.01 & 5.62 & 22.69 & 27.80 & 26.85 & & & & & & \\
\hline $\operatorname{liq}_{t}$ & 7.27 & 22.66 & 14.88 & 18.28 & 21.71 & $l i q_{t}$ & 6.58 & 24.14 & 14.44 & 14.62 & 15.36 \\
\hline$p c_{t}$ & 5.21 & 6.11 & 7.34 & 7.24 & 6.97 & $p c_{t}$ & 8.92 & 19.06 & 45.41 & 47.58 & 47.70 \\
\hline$y w_{t}$ & 0.00 & 2.19 & 10.34 & 12.02 & 11.80 & $y w_{t}$ & 0.01 & 2.28 & 4.34 & 5.05 & 5.05 \\
\hline resx $x_{t}$ & 0.00 & 2.58 & 1.76 & 1.36 & 1.28 & resx $x_{t}$ & 0.01 & 3.10 & 1.87 & 1.71 & 1.67 \\
\hline $\operatorname{comm}_{t}$ & 0.08 & 0.22 & 3.58 & 2.79 & 2.63 & $\operatorname{comm}_{t}$ & 0.01 & 0.13 & 2.38 & 2.18 & 2.12 \\
\hline$y d_{t}$ & 0.04 & 3.40 & 2.09 & 1.62 & 1.53 & $y d_{t}$ & 0.82 & 2.27 & 1.31 & 1.20 & 1.17 \\
\hline$p d_{t}$ & 0.15 & 3.17 & 1.99 & 1.54 & 1.45 & $p d_{t}$ & 0.10 & 2.83 & 1.63 & 1.49 & 1.45 \\
\hline$r d_{t}$ & 86.22 & 49.47 & 29.82 & 23.08 & 21.76 & $r d_{t}$ & 83.57 & 41.31 & 23.35 & 21.35 & 20.79 \\
\hline$q_{t}$ & 0.00 & 4.59 & 5.50 & 4.27 & 4.03 & $q_{t}$ & 0.00 & 4.88 & 5.27 & 4.82 & 4.69 \\
\hline
\end{tabular}

tests for the significance of the commodity sector variables, liquidity and world output. The first four rows of the table test for the joint effect of each variable individually. The tests conclude that each of the variables is significant in the model for Brazil at the $1 \%$ level of significance. Tests of the significance of the joint effect of the commodity sector comprising Chinese steel production and commodity prices reject the null hypothesis, as does the test of the joint effect of Chinese steel production, liquidity, commodity prices, and world output. These tests confirm the importance of the role of all of the elements of the international sector for Brazil.

\section{Historical decomposition}

This section contains the historical decompositions of output and the interest rate for Brazil over the sample period in Figures 3 and 4, respectively. The decompositions present the deviation of each variable around their trend, as indicated by the horizontal axis. The bars on the chart represent the actual values of output or the interest rate, and the baseline is the 
Table 3: Likelihood ratio tests of international linkages with Brazil, 1999Q1 to 2019Q1

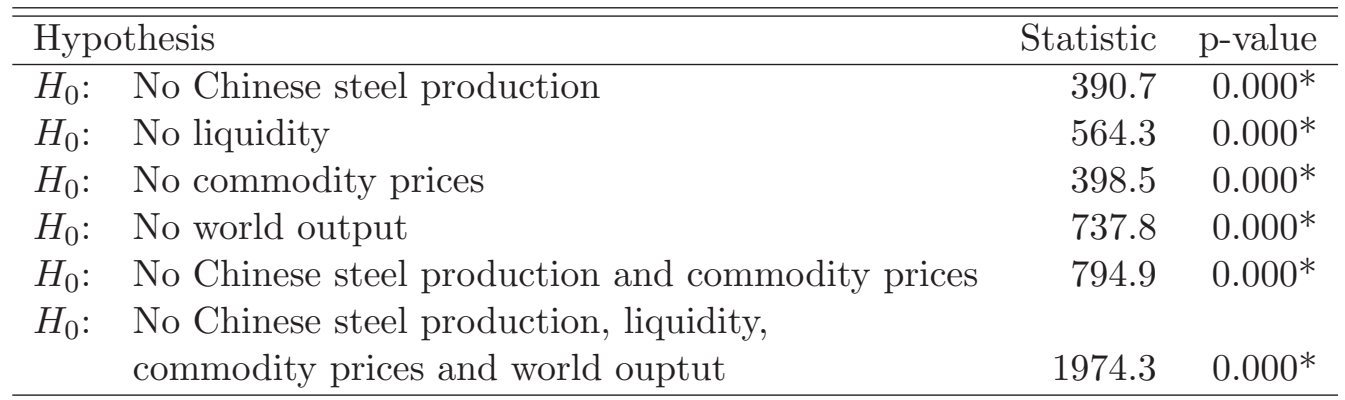

*Denotes significance at the 0.05 level.

forecast of each variable from the parameter estimates of the SVAR model. The remaining lines on the graphs show the contribution of the relevant shocks in the model to the evolution of each variable.

Historical decomposition of output The baseline forecast tracks realized output well. Positive turning points occur in both the output series and the baseline projection in 2003Q3, and negative turning points occur in 2011Q2. Output remains above the baseline projection for all of this time except for a year during the great financial crisis. By 2015Q1, the relationship between output and the baseline projection of output switches when the projection rises above the actual and remains that way until the end of the sample period. The Chinese resource demand shocks dominate the deviation between the baseline projection and actual output. Between 2005Q1 and the peak of the baseline projection of output in 2011Q2, only Chinese resource demand and a small amount from foreign output positively contribute to keeping output above trend. Chinese resource demand contributes positively until 2015Q1 when the relationship between output and the projection of output switches. This switching point coincides with the end of the resources boom coming from China. After this, Chinese resource demand is the main reason for Brazilian output being below trend. ${ }^{11}$ This result is also consistent with the interpretation of Cashin et al. (2017) who finds that the contraction in the value of China's imports from 2014 compounds concerns of negative spillovers from China to commodity-exporting economies as China reorients its growth to domestic sources. ${ }^{12}$

Before the financial crisis, international liquidity and commodity prices contribute negatively to output. These relationships change after the financial crisis with both of the shocks keeping output above the steady-state. This period coincides with the surge in international liquidity because of global policy responses to the financial crisis. The negative effect of commodity price shocks on output may be a reflection of time lags needed for the economy to adjust to benefit from the boom in demand for resource exports, particularly as the domestic currency appreciates substantially. ${ }^{13}$ Although international liquidity, commodity prices, and foreign

\footnotetext{
${ }^{11}$ Dungey et al. (2019) also date the beginning of the resource boom as 2005Q1 for Australia, the same as we do here for Brazil. They date the beginning of the unwinding of the boom as 2012Q2, one year after Chinese resource demand begins to have adverse effects on output for Brazil.

${ }^{12}$ According to the Getúlio Vargas Foundation's Business Cycle Dating Committee, Brazil was in recession from 2014Q2 to 2016Q4. The reports are available at https://portalibre.fgv.br/main.jsp?lumChannelId= 4028808126B9BC4C0126BEA1755C6C93.

${ }^{13}$ Dungey et al. (2019) find that commodity prices negatively affected the Australian economy during the same period, attributing the reason to the economy needing time to adjust structurally to accommodate the boom in exports and the appreciation of the domestic currency across the economy. Their results also show
} 


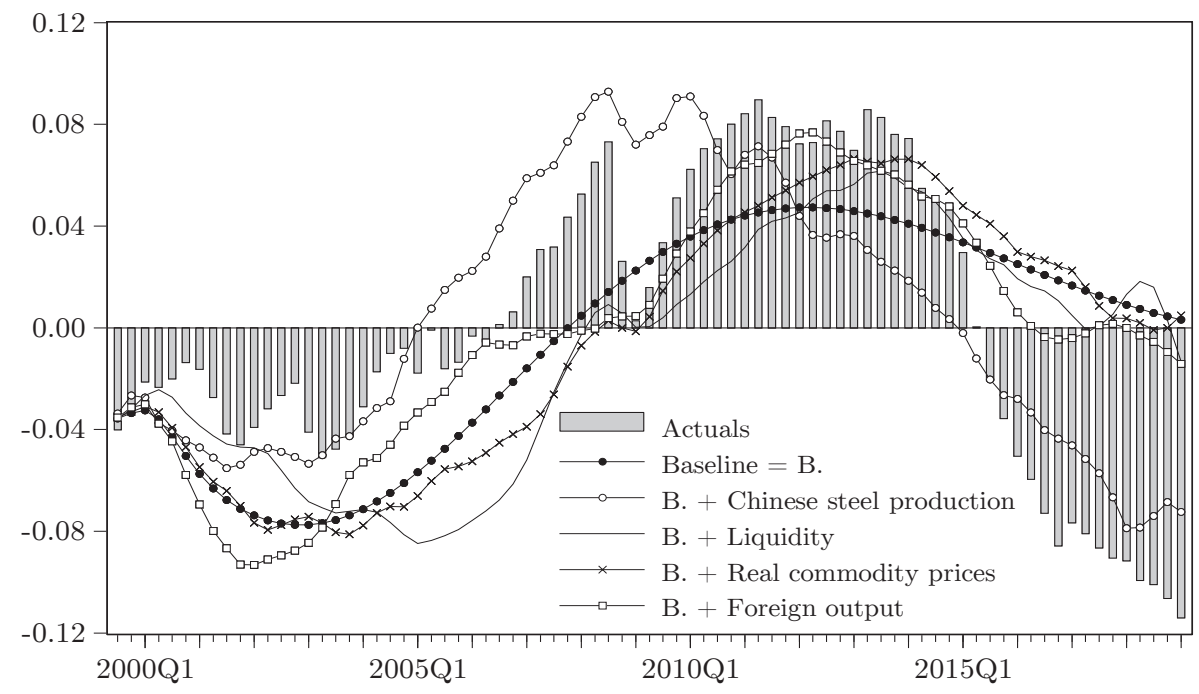

Figure 3: Historical decomposition of output for Brazil, 1999Q1 to 2019Q1.

output are not the dominant drivers of Brazilian output, the decomposition shows that they had an essential role between 2010Q1 and 2017Q2 in offsetting the contractionary effects of the Chinese resource demand shocks as the Chinese sourced boom unwound.

\section{Historical decomposition of the interest rate}

The bars in the panels of Figure 4 show the deviation of the interest rate from its trend along the horizontal axis. At the beginning of the sample, the fundamentals of Brazil are regarded as weak by international investors, and the interest rate remains above trend until 2003Q2. The interest rate available to Brazil falls below trend after this time, where it remains favorable until 2014Q4. The baseline projection and the shocks in the model track the interest rate quite well. The only shock systematically influencing the evolution of the interest rate series is Chinese steel production (Figure 4a). Domestic variables have a weak influence on the interest rate during the sample period (Figure $4 \mathrm{~b}$ ). The improvement in the interest rate corresponds to Chinese steel production, which has a downward influence on the interest rate from 2000Q2, well before the beginning of the commodity boom dated above as beginning in 2005Q1, reflecting the buildup towards the commodities boom. As the commodity boom in China begins to unwind, and Chinese resource demand declines, borrowing conditions for Brazil deteriorate.

\section{Robustness}

This section examines the robustness of the model to alternative assumptions for the model and the data by focusing on the variance decomposition of output. The results show that the model is relatively robust as domestic variables contribute to the variance of output in the short-run, but Chinese resource demand and liquidity are more critical in the long-run.

that commodity price shocks affect the economy positively after the financial crisis. 


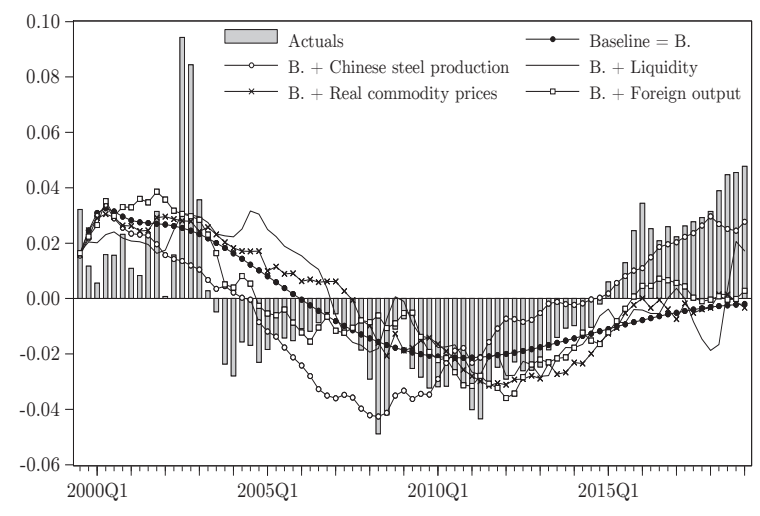

(a) international

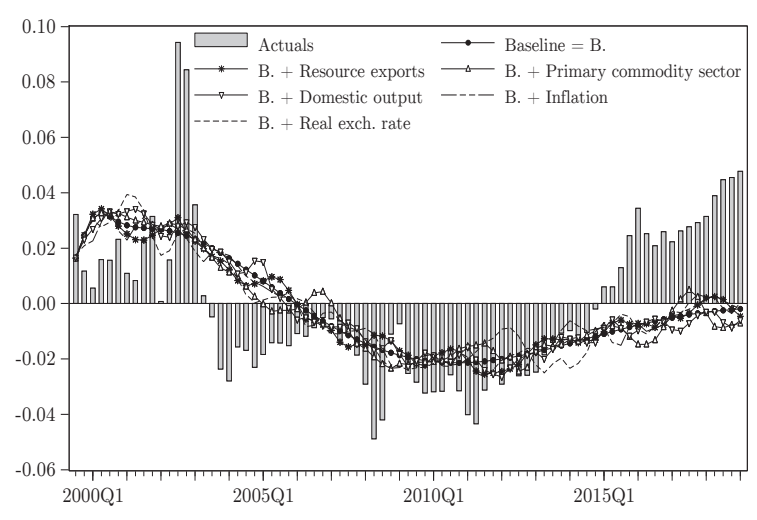

(b) domestic

Figure 4: Historical decomposition of the interest rate for Brazil, 1999Q1 to 2019Q1. Panel (a) contains the international contributions and panel (b) contains the domestic contributions.

Five robustness exercises are undertaken and displayed in the format of a stacked bar graph of the contributions of the variables to the variance of output in Figure 5. The top panel of the figure contains the contributions of the variables to the overall variance of output after four quarters. The second panel presents the same information for output after 36 quarters. The contributions of the variables in the benchmark model worked with throughout the paper are presented for comparison in the same format in columns (a). The robustness exercises first examine alternative proxies for Chinese resource demand. Columns (b) replaces Chinese resource demand with Chinese GDP in the model, and columns (c) replaces it with Chinese industrial production. Columns (d) relaxes the treatment of the trends by not detrending the data and estimating the model with all variables in log levels. ${ }^{14}$ Columns (e) explore the effect of ordering commodity prices in the model before Chinese resource demand, while columns (f) provide an alternative specification for the domestic sector.

Over both horizons of the variance decompositions presented, the contributions of the domestic shocks are similar to the benchmark case. Domestic shocks contribute from 18 to $30 \%$ to the variance of output in the four-quarter horizon, but in the 36 quarter horizon, contribute less than $6 \%$ compared to the benchmark contributions of $22 \%$ and $4 \%$ for horizons 4 and 36 , respectively.

Alternative proxies for Chinese resource demand result in lower contributions of resource demand in the short- and long-run with the proxy of Chinese GDP. In the benchmark case, Chinese resource demand contributes $39 \%$ in quarter four compared to $5 \%$ when Chinese GDP proxies resource demand. In contrast, Chinese industrial production contributes more than $60 \%$ in the short-run, reflecting that industrial production is more resource-intensive than GDP, while the percentage contribution of industrial production is similar in magnitude to the benchmark case after 36 quarters.

Keeping the trends in the data has a qualitatively similar story to the benchmark case, with the foreign sector shocks more critical than domestic shocks after 36 quarters. The decomposition in the longer term is slightly different from the benchmark, with the influence of liquidity smaller and the influence of commodity prices larger. However, Chinese steel

\footnotetext{
${ }^{14}$ Inflation remains in percent.
} 

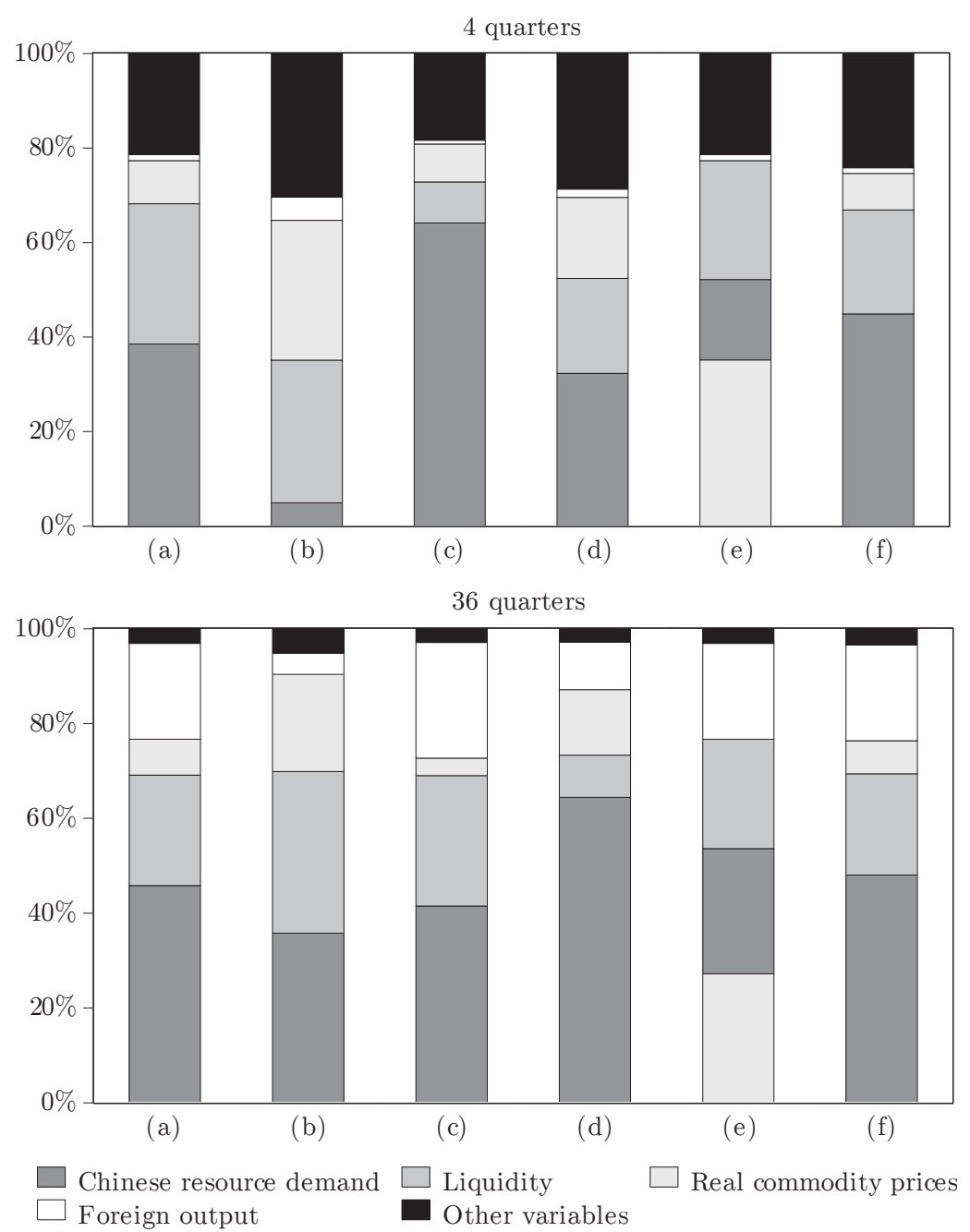

Figure 5: Variance decomposition of output for alternative models, 1999Q1 to 2019Q1. The alternative models are: (a) benchmark; (b) Chinese GDP instead of Chinese steel production; (c) Chinese industrial production instead of Chinese steel production; (d) no detrending; (e) order commodity prices first; and (f) alternative specification of the domestic sector for Brazil. 
Table 4: Granger causality tests of the international variables, 1999Q1 to 2019Q1

\begin{tabular}{lll}
\hline \hline Hypothesis & p-value \\
\hline$H_{0}: \quad$ Chinese steel production does not Granger cause international liquidity & $0.009^{*}$ \\
$H_{0}: \quad$ Chinese steel production does not Granger cause commodity prices & $0.004^{*}$ \\
$H_{0}: \quad$ Chinese steel production does not Granger cause foreign output & 0.095 \\
$H_{0}: \quad$ International liquidity does not Granger cause Chinese steel production & $0.007^{*}$ \\
$H_{0}: \quad$ International liquidity does not Granger cause commodity prices & $0.002^{*}$ \\
$H_{0}: \quad$ International liquidity does not Granger cause foreign output & 0.187 \\
$H_{0}: \quad$ Commodity prices does not Granger cause Chinese steel production & $0.012^{*}$ \\
$H_{0}: \quad$ Commodity prices does not Granger cause international liquidity & $0.004^{*}$ \\
$H_{0}: \quad$ Commodity prices does not Granger cause foreign output & 0.202 \\
$H_{0}: \quad$ Foreign output does not Granger cause Chinese steel production & 0.138 \\
$H_{0}: \quad$ Foreign output does not Granger cause international liquidity & $0.015^{*}$ \\
$H_{0}: \quad$ Foreign output does not Granger cause commodity prices & 0.419 \\
\hline$*$ Denotes significance at the 0.05 level. &
\end{tabular}

production still dominates.

Changing the order of the foreign sector so that commodity prices come before Chinese steel production does not change the overall magnitude of the foreign sector to domestic output, with it still being above $90 \%$ after 36 quarters, but it does change the contribution of the elements of the foreign sector. After 36 quarters, commodity prices, Chinese steel production, liquidity, and foreign output contribute similar magnitudes, ranging between $20 \%$ and $27 \%$. We undertook Granger causality tests of the variables in the model and found that they provide little evidence to assist in deciding on an ordering of the international variables in the model. The $p$-values of the tests for the international variables are contained in Table 4. However, we are satisfied with our choice of ordering the international sector with Chinese resource demand coming first, as in addition to the rationale in Section 2, the only variable that Chinese resource demand does not Granger cause in the model is inflation. ${ }^{15}$ No other variable, including commodity prices, has such a significant effect on all variables in the model.

The final robustness exercise specifies a different domestic sector for Brazil, sometimes used in papers on emerging markets (Shousha, 2016; Zeev et al., 2017). The alternative domestic component of the model consists of domestic output, consumption, investment, the trade balance to GDP ratio, the interest rate, and the real exchange rate. Again, the contribution of Chinese steel production dominates (48\%), followed by liquidity (21\%), world output (20\%), and finally commodity prices $(7 \%)$, which is again much lower than found in previous work.

\section{Conclusion}

Commodity exporting emerging market economies are subject to external shocks that can substantially affect the macroeconomy. Several recent papers look at the counter-cyclical

\footnotetext{
${ }^{15}$ Chinese resource demand does not Granger cause foreign output at the $5 \%$ level, but does at the $10 \%$ level of significance.
} 
nature of the cost of borrowing from global financial markets for emerging markets, which can affect macroeconomic outcomes as sovereign risk is built into country interest rate spreads (Neumeyer and Perri, 2005; Uribe and Yue, 2006). As an economy improves, the interest rate on offer falls (Fernández and Gulan, 2015; Fernández et al., 2018). The literature has also shown that the omission of commodity prices for emerging markets leads to the overstatement of interest rate shocks on business cycles (Shousha, 2016). Using the case study of Brazil, our work shows that relying only on commodity prices overstates the effect of commodity prices on the macroeconomy. We carefully identify both commodity demand and supply shocks in an SVAR model for Brazil by including Chinese steel production as a proxy for commodity demand in addition to commodity prices (Dungey et al., 2014, 2019). We also build on Ratti and Vespignani (2015) who show that liquidity influences commodity prices by including international liquidity in the macroeconomic model.

The impulse response functions show that Chinese steel production shocks do, indeed, behave as commodity demand shocks, and commodity price shocks are like commodity supply shocks. Our results show that commodity demand shocks, rather than commodity price shocks, have a substantial effect on the macroeconomy of Brazil. They are larger in both magnitude and duration. Both international liquidity and world output shocks matter more than commodity price shocks once we include commodity demand shocks. Commodity price shocks are expansionary, but not persistent. The historical decompositions for output and the interest rate show that Chinese resource demand has an expansionary effect on both variables, output between 2005 and 2015, and the interest rate between 2001 and 2014. In the long term, the effects of domestic shocks in explaining the variance in output are negligible.

Our results confirm those of Shousha (2016), who shows that the inclusion of commodity price shocks in the model dampens the contribution of interest rate shocks on domestic output. We also show that including Chinese resource demand and liquidity in the model lowers the contribution of world commodity prices in explaining the variance of the interest rate compared to that found in the previous literature with the implication that the interest rate plays a smaller role in explaining the variance in domestic output than that found in previous work. The shock to international liquidity leads to an increase in real commodity prices. We extend Ratti and Vespignani (2015) to show that liquidity shocks lead to a domestic currency appreciation and a fall in the interest rate in Brazil, in turn, stimulating domestic output. We also find that liquidity responds to the demand shock coming from China, but not to the supply shock reflected in the commodity price series.

\section{References}

Aslam, A., Beidas-Strom, S., Bems, R., Celasun, O., Çelik, S. K., Koczan, Z., 2016. Trading on their terms? Commodity exporters in the aftermath of the commodity boom. IMF Working Paper No. 16/27.

Barone, S., Descalzi, R., 2012. Endogenous risk premium and terms of trade shocks: Evidence for developing countries. Revista de economía 19 (2), 7-39.

Bastourre, D., Carrera, J., Ibarlucia, J., Sardi, M., 2012. Common drivers in emerging market spreads and commodity prices. Central Bank of Argentina Working Paper No. 12/57. 
Benigno, G., Converse, N., Fornaro, L., 2015. Large capital inflows, sectoral allocation, and economic performance. Journal of International Money and Finance 55, 60-87.

Berkelmans, L., 2005. Credit and monetary policy: An Australian SVAR. Reserve Bank of Australia Research Discussion Paper No. 05/06, 1-32.

Bouri, E., Boyrie, M. E., Pavlova, I., 2016. Volatility transmission from commodity markets to sovereign CDS spreads in emerging and frontier countries. International Review of Financial Analysis 49, 155-165.

Cashin, P., Céspedes, L. F., Sahay, R., 2004. Commodity currencies and the real exchange rate. Journal of Development Economics 75 (1), 239-268.

Cashin, P., Mohaddes, K., Raissi, M., 2017. China's slowdown and global financial market volatility: Is world growth losing out? Emerging Markets Review 31, 164-175.

Cesa-Bianchi, A., Pesaran, M. H., Rebucci, A., Xu, T., Chang, R., 2012. China's emergence in the world economy and business cycles in Latin America. Economía 12 (2), 1-75.

Choi, W. G., Kang, T., Kim, G.-Y., Lee, B., 2017. Global liquidity transmission to emerging market economies, and their policy responses. Journal of International Economics 109, $153-166$.

Corden, W. M., 1984. Booming sector and Dutch disease economies: Survey and consolidation. Oxford Economic Papers 36, 359-380.

Corden, W. M., Neary, J., 1982. Booming sector and de-industrialisation in a small open economy. The Economic Journal 92, 825-848.

Deaton, A., Miller, R., 1996. International commodity prices, macroeconomic performance, and policies in Sub-Saharan Africa. Journal of African Economies 5 (3), 99-1991.

Drechsel, T., Tenreyro, S., 2018. Commodity booms and busts in emerging economies. Journal of International Economics 112, 200-218.

Dungey, M., Fry-McKibbin, R., Linehan, V., 2014. Chinese resource demand and the natural resource supplier. Applied Economics 46 (2), 167-178.

Dungey, M., Fry-Mckibbin, R., Volkov, V., 2019. Transmission of a resource boom: The case of Australia. Oxford Bulletin of Economics and Statistics.

Dungey, M., Pagan, A., 2000. A structural VAR model of the Australian economy. Economic Record 76 (235), 321-342.

Fernández, A., González, A., Rodriguez, D., 2018. Sharing a ride on the commodities roller coaster: Common factors in business cycles of emerging economies. Journal of International Economics 111, 99-121.

Fernández, A., Gulan, A., 2015. Interest rates, leverage, and business cycles in emerging economies: The role of financial frictions. American Economic Journal: Macroeconomics 7 (3), 153-188.

Frankel, J., 2012. The natural resource curse: A survey of diagnoses and some prescriptions. Harvard Kennedy School Research Working Paper Series RWP12-014. 
Hilscher, J., Nosbusch, Y., 2010. Determinants of sovereign risk: Macroeconomic fundamentals and the pricing of sovereign debt. Review of Finance, 235-262.

Jääskelä, J. P., Smith, P., 2013. Terms of trade shocks: What are they and what do they do? Economic Record 89 (285), 145-159.

Kang, H., Yu, B.-K., Yu, J., 2016. Global liquidity and commodity prices. Review of International Economics 24 (1), 20-36.

Neumeyer, P. A., Perri, F., 2005. Business cycles in emerging economies: The role of interest rates. Journal of Monetary Economics 52 (2), 345-380.

Ornelas, J., 2017. Risco, Dívida e Alavancagem Soberana. Central Bank of Brazil Working Paper 457.

Ratti, R. A., Vespignani, J. L., 2013. Crude oil prices and liquidity, the BRIC and G3 countries. Energy Economics 39, 28-38.

Ratti, R. A., Vespignani, J. L., 2015. Commodity prices and BRIC and G3 liquidity: A SFAVEC approach. Journal of Banking \& Finance 53, 18-33.

Shousha, S., 2016. Macroeconomic effects of commodity booms and busts: The role of financial frictions. Unpublished Manuscript.

Uribe, M., Yue, V. Z., 2006. Country spreads and emerging countries: Who drives whom? Journal of international Economics 69 (1), 6-36.

van Wijnbergen, S., 1984. The Dutch disease: A disease after all? The Economic Journal 94, $41-55$.

Veríssimo, M. P., Xavier, C. L., 2013. Taxa de câmbio, exportações e crescimento: uma investigação sobre a hipótese de doença holandesa no brasil. Brazilian Journal of Political Economy 33 (1), 82.

Zeev, N. B., Pappa, E., Vicondoa, A., 2017. Emerging economies business cycles: The role of commodity terms of trade news. Journal of International Economics 108, 368-376.

\section{A Data appendix}

Items $(i)$ to (viii) below contain descriptions of the data used in the benchmark model in this article. Items $(i x)$ to $(x)$ contain the data used in the robustness exercises in Section 6. Plots of the data for the benchmark model are given in Figure 6.

(i) Chinese steel production $\left(c s p_{t}\right)$ : In tonnes. The monthly data are converted to quarterly data by summing the values of the quarter; these data are seasonally adjusted using ARIMA X13. The data source is Datastream (code: CHVALSTLH). We replace missing data with estimates from the World Steel Association.

(ii) Liquidity $\left(l i q_{t}\right)$ : The M2 data for Brazil, Russian Federation, China, and the U.S. are from Brazilian Institute of Applied Economic Research, Central Bank of Russia Federation, International Monetary Fund and Federal Reserve Board, respectively. The L2 data for India 
is from the Reserve Bank of India. The exchange rate data and the consumer price indexes are from the Federal Reserve Bank of St. Louis.

(iii) Real commodity prices $\left(p c_{t}\right)$ and resource exports $\left(r e s x_{t}\right)$ : Nominal commodity prices in U.S. dollars, monthly. We deflate the data using the U.S. CPI for All Urban Consumers. The sources are The World Bank (WB) Pink Sheet and the Bureau of Labor statistics. Brazilian exports in U.S. dollars are used to derive the weights to construct the real commodity price index and to calculate the value of Brazilian resource exports. The export data come from the Comex Stat. We consider all the traded commodities included in the WB Pink Sheet for ranking the three most traded commodities for Brazil in the sample period (soybeans - SITC code: 222; crude oil - SITC code: 3330; iron ore - SITC codes: 2815, 2816, 2814). The export series is deflated by the U.S. CPI and seasonally adjusted using ARIMA X13.

(iv) Foreign output $\left(y w_{t}\right)$ : Constant U.S. dollars and seasonally adjusted. The source is the World Bank - Global Economic Monitor. Export data are used to calculate the weights. The source is Comex Stat.

(v) Non-tradable primary commodity sector $\left(\right.$ comm $\left._{t}\right)$ and the Brazilian GDP (domestic output) $\left(y d_{t}\right)$ : The source is the Brazilian System of National Accounts of the Brazilian Institute of Geography and Statistics (IBGE). The data are chain-weighted in 1995 prices and seasonally adjusted.

(vi) Inflation $\left(p d_{t}\right)$ : The source is the Brazilian Institute of Geography and Statistics (IBGE) (code: 433).

(vii) Interest rate $\left(r d_{t}\right)$ : The sum of JP Morgan's Emerging Markets Bond Index (EMBI+ Brazil) and the U.S. real interest rate. The source of the JP Morgan EMBI+ is the Brazilian Institute of Applied Economic Research (IPEA). The source of data on the three-month U.S. Treasury bill and the measure of U.S. expected inflation is the Federal Reserve Bank of St. Louis.

(viii) Real exchange rate $\left(q_{t}\right)$ : The source is the Central Bank of Brazil (code: 11752).

(ix) Chinese GDP and Chinese industrial production: Constant U.S. dollars and seasonally adjusted. The source is the World Bank - Global Economic Monitor.

$(x)$ Consumption, investment and trade balance to GDP ratio: The source is the Brazilian System of National Accounts of the Brazilian Institute of Geography and Statistics (IBGE). The data are chain-weighted in 1995 prices and seasonally adjusted. 

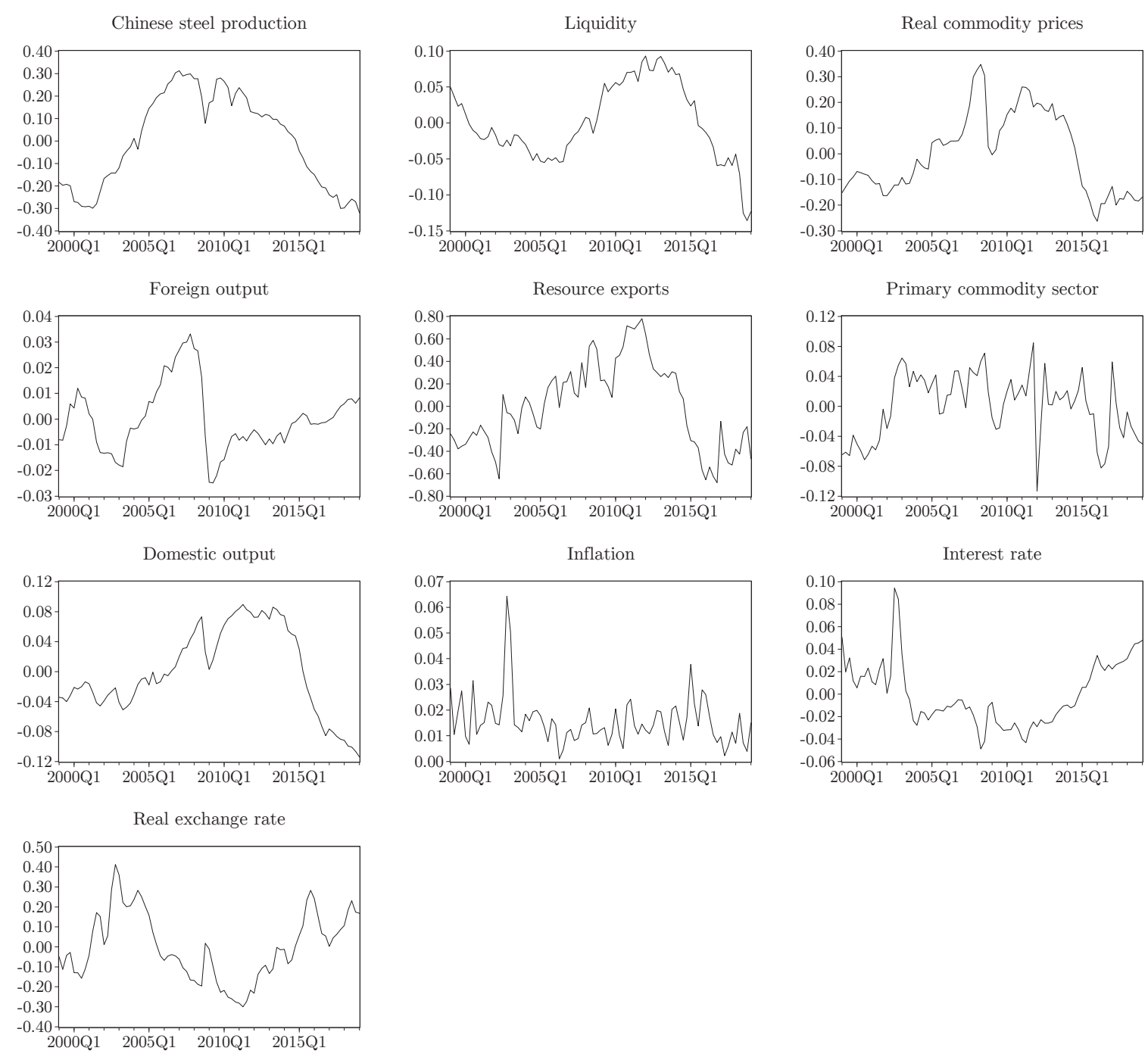

Figure 6: Plots of the variables in the commodity model for Brazil, 1999Q1 to 2019Q1. 